Recebido: $16 / 08 / 2015$

Aprovado: 12/02/2016

\title{
Revisionismo histórico online: Valhalla88, o difusor da intolerância na América do Sul (1997-2007)*
}

Monica da Costa Santana**

Resumo: Este artigo tem como proposta analisar as atividades antissemitas desenvolvidas pelo website brasileiro, Valhalla88 (www.valhalla88.com), entre os anos de 1997 a 2009. Apoiando-se nas teorias revisionistas, o grupo que mantinha o sítio em atividade objetivava desconstruir a ideia de Auschwitz como campo de extermínio nazista. Para legitimarem suas propostas, utilizaram um diversificado acervo de textos de conhecidos autores revisionistas, a exemplo de Paul Rassinier e Robert Faurisson, e imagens de caráter antissemitas. Nosso intuito é entender as formas de ativismo político, desenvolvidas por movimentos de extrema-direita neonazistas, assim como investigar as diferentes estratégias de abordagem desses grupos possibilitadas pelo meio digital.

Palavras-chave: neonazismo; antissemitismo; revisionismo.

\begin{abstract}
This article aims to analyze the anti-Semitic activities developed by the Brazilian website, Valhalla88 (www.valhalla88.com), between the years 1997 to 2009. Building on the revisionist theories, the group that kept the site in activity aimed to deconstruct the idea as Auschwitz Nazi death camp. To legitimize their proposals, they used a diverse collection of texts known revisionist authors, like Paul Rassinier and Robert Faurisson, and anti-Semitic character images. Our aim is to understand the forms of political activism, developed by movements of far-right neo-Nazis, as well as investigate the different approach strategies of these groups possible by digital means.
\end{abstract}

Keywords: neo-Nazism; anti-Semitism; revisionism

\footnotetext{
* Esse texto faz parte do terceiro capítulo da minha dissertação de mestrado, intitulada "Neonazismo no ciberespaço do Brasil e da Argentina: análise comparada dos sítios Valhalla88 e Ciudad Libre Opinión (19972009)", defendida em março de 2014 pelo Programa de Pós-Graduação em História Comparada (PPGHC/UFRJ).

** Doutoranda do Programa de Pós-Graduação em História Comparada (PPGHC/UFRJ). Bolsista da Coordenação de Aperfeiçoamento de Pessoal de Nível Superior (CAPES). E-mail: monica.ifcs@gmail.com
} 


\section{Revisionismo histórico: uma breve análise}

De acordo com Pierre Vidal-Naquet, "mal a guerra terminou, começaram os trabalhos sobre o universo dos campos de concentração" (1988: 29). Estes trabalhos não estão relacionados apenas com o esclarecimento dos crimes cometidos pelos nazistas. Também podemos incluir a produção de trabalhos que tinham como objetivo relativizar os acontecimentos divulgados após a Segunda Guerra Mundial (1939-1945).

O Revisionismo histórico ou Negacionismo ${ }^{1}$, como ficou conhecido, começou a ser definido a partir da década de 1950 e ganhou adeptos em várias partes do mundo. Segundo Luiz Milman, “o negacionismo passa, a partir dos anos 70, a ser um elemento central de uma estratégia que se destina a criar condições para a recomposição ideológica de grupos políticos nazistas" (2000: 132). Ao longo desse período foram produzidos inúmeros materiais que atualmente tem servido para grupos extremistas construírem suas justificativas no processo de reorganização de movimentos identificados com o nazismo, na tentativa de recolocá-los no cenário político do século XXI.

Milman nos chama a atenção para um ponto importante relacionado às discussões em torno desse tema:

O negacionismo, numa perspectiva estritamente historiográfica, não é uma interpretação alternativa, nem reacionária, nem mesmo nazistófila, do hitlerismo. Ele é uma construção ideológica de aparência histórica e, nessa condição, não suscita problemas ao nível da compreensão do Holocausto e das suas consequências. O desafio que os negacionistas nos apresentam [referindo-se aos historiadores] é de outra natureza: na medida em que constroem uma versão fictícia da História e que essa versão produz efeitos políticos, os negacionistas obrigam-nos não somente a refutá-los, mas fazermos uma reflexão sobre a relevância do papel da História e da memória para a educação humanista (2000: 123).

A pertinente observação feita por Milman nos leva ao ponto fundamental para a História. Ele está intimamente ligado à veracidade do conhecimento histórico que pode ser

\footnotetext{
${ }^{1}$ De acordo com Dietfrid Krause-Vilmar, a negação pública dos crimes nazistas, que mais tarde passou a ser chamada de Revisionismo - porque seus adeptos diziam pretender re-visar a História - surgiu primeiramente na França e, mais tarde, nos Estados Unidos, na Grã-Bretanha, na Espanha, na Bélgica, Canadá e, relativamente cedo, também na Alemanha. Inicialmente, tais pessoas ainda não negavam que tivesse ocorrido essa matança em massa por meio do uso de gás tóxico ou gás asfixiante. $\mathrm{O}$ que elas fizeram inicialmente foi relativizar as declarações das testemunhas da época. Cf. KRAUSE-VILMAR, Dietfrid. A negação dos assassinatos em massa do nacional-socialismo: desafios para a ciência e para a educação política. In: VIZENTINI, Paulo Fagundes; MILMAN, Luis (Orgs). Neonazismo, Negacionismo e Extremismo Político. Porto Alegre: Editora da Universidade/UFRG: CORAG, 2000: 103-104.
} 
resumido na seguinte questão: existe verdade na História? A partir desse momento, nos deparamos com um tema complexo e, ao mesmo tempo, essencial para a construção de nossa percepção sobre o mundo. Não é nossa intenção nos aprofundarmos neste assunto, no entanto, entendemos a sua importância diante das implicações políticas e sociais, sendo necessário nos posicionarmos diante de tal questão.

A História é reescrita continuamente. Essa afirmação feita por José Carlos Reis tem como justificativa, segundo o próprio autor, duas possíveis razões: "Em primeiro lugar, pela especificidade mesma do objeto do conhecimento histórico: os homens e as sociedades humanas no tempo [...]. Em segundo lugar, a história é reescrita porque o conhecimento histórico muda, acompanhando as mudanças da história.” (REIS, 2001: 7-9).

Essas características tão particulares à História têm sido motivo de intensos debates entre historiadores que apresentam diferentes posicionamentos diante dessas particularidades. Esses debates se intensificaram a partir dos anos de 1960, com a virada linguística (linguistic turn) ${ }^{2}$, acontecimento que influenciou e reforçou o pensamento pós-modernista ${ }^{3}$ com importantes desdobramentos para a historiografia.

A influência de todo esse complexo conjunto de ideias sobre o pensamento historiográfico manifestou-se, sobretudo, na consideração do 'discurso historiográfico', questão à qual se encontra ligada a própria possibilidade de um conhecimento objetivo da História e a natureza do trabalho do historiador [...] (ARÓSTEGUI, 2006: 184).

É importante ressaltar a contribuição do pós-modernismo na construção de debates que têm aprimorado o processo de conhecimento histórico. No entanto, os desdobramentos advindos das concepções pós-modernistas também proporcionaram o surgimento de alguns equívocos. Sendo, talvez, o principal deles, a radicalização do relativismo.

\footnotetext{
${ }^{2}$ Linguistic turn ou giro linguístico, de "caráter filosófico em sua origem, ligado também à semiótica [...]. [sustenta que] a língua seria o molde final em todo conhecimento humano, que cria, inclusive, a realidade exterior pois esta não pode ser captada de outra forma senão pelo sinal linguístico". Cf.: ARÓSTEGUI, Julio. A pesquisa histórica: teoria e método. Bauru, SP: EDUSC, 2006: 182-184.

3 "Num sentido muito geral, o pós-modernismo sustenta a proposição que a sociedade ocidental passou nas últimas décadas por uma mudança de uma era moderna para uma pós-moderna, a qual se caracterizaria pelo repúdio final da herança da ilustração, particularmente da crença na Razão e no Progresso, e por uma insistente incredulidade nas grandes metanarrativas, que imporiam uma direção e um sentido à História, em particular a noção de que a história humana é um processo de emancipação universal. No lugar dessas grandes metanarrativas surge agora uma multiplicidade de discursos e jogos de linguagem, o questionamento da natureza do conhecimento junto com a dissolução da ideia de verdade, e outros problemas de legitimação em vários campos." Cf.: MALERBA, Jurandir. Ensaios: teoria, história e ciências sociais. Londrina: Eduel, 2011: 124.
} 
As principais bases do pós-modernismo assentam em sua concepção de linguagem e na negação do realismo (MALERBA, 2011: 125) ${ }^{4}$, a partir do momento que perdemos o referencial de realidade, causando a dissolução da ideia de verdade, estamos sujeito as mais variadas e dúbias formas de apropriação da História. Como bem disse Felipe FernandezArmesto, "quando as pessoas cessam de acreditar em alguma coisa, não passam a não acreditar em nada, mas a acreditar em qualquer coisa." (2000: 17).

A fronteira que separa a ficção da realidade torna-se tênue, transformando a História em um campo aberto, susceptível aos diversificados usos ideológicos. Eric Hobsbawm nos advertia: "a história é a matéria-prima para as ideologias nacionalistas ou étnicas ou fundamentalistas, tal como as papoulas são a matéria-prima para o vício da heroína" (HOBSBAWM, 1998: 17). Neste sentido, o passado se transforma em um elemento essencial a essas ideologias e, "se não há nenhum passado satisfatório, sempre é possível inventá-lo" (HOBSBAWM, 1998: 17). É a partir dessa perspectiva que os revisionistas têm acionado o passado no intuito de legitimar-se no presente.

As ideias defendidas pelos revisionistas são construídas através do questionamento, da negação e da colocação em dúvida dos acontecimentos históricos. Os seus objetivos não são genuinamente histórico-científicos, como querer esclarecer ou averiguar o que realmente aconteceu. Seus objetivos estão intimamente ligados a fatores políticos, o que eles querem é provar que não foi assim e, dessa maneira, poder reabilitar Hitler e o nacional-socialismo (KRAUSER-VILMAR, 2000: 117).

A manipulação de documentos e a tentativa de subverter os acontecimentos têm sido comumente utilizadas em suas teorias sobre os campos de concentração nazistas. Pierre Vidal-Naquet, em sua obra Os assassinos da memória (1988), nos aponta os princípios do método utilizado pelos revisionistas no processo de construção de suas ideias:

1. Todo testemunho direto de um Judeu é uma mentira ou imaginação; 2. Todo testemunho, todo documento anterior à liberação é falso, ignorado ou considerado "boato"; 3. Em geral, todo documento que nos informa em primeira mão sobre os métodos nazistas é falso ou manipulado; 4. Todo documento nazista que traz um testemunho direto é comprometido em seu sentido literal se escrito em códigos, mas ignorado (ou subinterpretado) se escrito em linguagem direta [...]. 5. Consideram que todo testemunho nazista posterior ao final da guerra, nos processos do Leste ou Oeste, em Varsóvia

\footnotetext{
${ }^{4}$ Para Jurandir Malerba, “[...] o pós-modernismo nega tanto a capacidade da linguagem ou discurso de referir a um mundo independente de fatos e coisas, quanto à determinação final - ou 'resolutibilidade' - do sentido do textual. A partir daí, ele nega também a possibilidade do conhecimento objetivo e da verdade como horizontes utópicos de qualquer investigação." (2011: 126).
} 
ou Colônia, Jerusalém e Nuremberg, em 1945 ou em 1963, foi obtido sob tortura ou intimidação; 6. Mobiliza todo um arsenal pseudotécnico para mostrar a impossibilidade material do extermínio maciço por gás; 7. [...] para os "revisionistas", as câmaras de gás não existem porque a inexistência é um de seus atributos. É a prova não-ontológica; 8. Enfim e principalmente tudo o que pode tornar conveniente e crível essa história terrível, marcar sua evolução, fornecer termos de comparação política, é ignorado ou falsificado (1988: 41-44).

Segundo Vidal-Naquet, o significado do método histórico dos revisionistas “é, em nossa sociedade de encenação e espetáculo, uma tentativa de extermínio no papel, que substitui o extermínio real" (1988: 45). A incessante busca por elementos que possam, de alguma maneira, se contrapor as informações divulgadas após a abertura dos campos de concentração pelos aliados é o principal objetivo dos autores revisionistas.

Entre esses autores destacamos Paul Rassinier e Robert Faurisson. ${ }^{5}$ Seus trabalhos têm sido repetidamente utilizados por grupos de extrema-direita neonazistas na tentativa de minimizar os crimes cometidos pelos nazistas e reconstruir a imagem de Adolf Hitler.

Paul Rassinier ficou conhecido como o pai do revisionismo. Nascido na França, em 1906, Rassinier chegou a lecionar História e Geografia na escola secundária de Faubourg de Montbeliard. Durante a Segunda Guerra Mundial participou da Resistência francesa sendo preso pela Gestapo, em 1943, e enviado para o campo de concentração de Buchewald e, posteriormente, para Dora-Nordhausse. Após ser libertado, escreveu um livro de memórias, intitulado Passagem da Linha, publicadas no final dos anos 40, no qual minimizava os relatos dos sobreviventes dos campos de concentração e, ao mesmo tempo, procurava desviar a culpa pela situação dos campos, responsabilizando os prisioneiros nomeados pela SS para administrar as tarefas e a supervisão sobre os demais prisioneiros (MELO, 2013: 7). A obra mais famosa desse autor intitula-se A Mentira de Ulisses (1950), na qual questiona de forma sistemática a literatura sobre o holocausto e nega a existência das câmaras de gás.

Outro autor revisionista bastante conhecido, tanto entre os grupos neonazistas quanto no meio acadêmico, é Robert Faurisson. Nascido em 1929, filho de pai francês e mãe britânica (escocesa), Faurisson lecionou na Sorbone e na Universidade de Lyon. ${ }^{6}$ Através dele, no final dos anos de 1970, o revisionismo começou a ser difundido no meio acadêmico. De acordo com Carlos G. Nóbrega de Jesus:

\footnotetext{
${ }_{6}^{5}$ Autores cujas obras eram frequentemente referenciados no sítio brasileiro, Valhalla88.

6 Informações obtidas através do sítio eletrônico Radioslam. Disponível em: www.radioislam.org/faurisson/por/vitorias-portug.htm acesso em 26 de janeiro de 2014.
} 
Apesar da falta de originalidade, Faurisson tem lugar de destaque nos meios negacionistas, pois foi a partir de seu trabalho que tal ideário aportou em países como Argentina, Austrália, Brasil, Canadá, além de haver sido aceito com grande simpatia nos Estados Unidos e na Alemanha (2006: 42).

Ainda segundo Nóbrega, Faurisson "foi pioneiro na estratégia de combinar várias teses revisionistas, antissemitas e nacionalistas em uma única linha argumentativa que aparentava cientificidade" (2006: 42), o que o transformou em um dos principais autores revisionistas no final do século XX e início do XXI.

Dietfrid Krause-Vilmar aponta que os revisionistas conseguiram construir uma enorme rede internacional de institutos que possuem programas de publicações de livros e revistas, principalmente em países como os Estados Unidos e a Bélgica (2000: 107). No Brasil, destacamos as atividades realizadas por Siegfried Ellwanger Castan e sua Editora Revisão (fundada em 1985, tendo suas atividades encerradas em 2009), localizada na cidade de Porto Alegre, no Estado do Rio Grande do Sul. Dentre os livros publicados por Castan através de sua editora estão: Holocausto: Judeu ou Alemão? Nos Bastidores da Mentira do Século (1987), Acabou o Gás!... Fim de um Mito (1989), entre outros. Os trabalhos de Castan contribuíram para incitar o ódio e a prática de atos antissemitas entre os grupos neonazistas, principalmente brasileiros.

Além disso, com a popularização da internet nos anos de 1990, os materiais produzidos por estes revisionistas passaram a ser difundidos de forma mais dinâmica, quando os neonazistas migraram para o ciberespaço ${ }^{7}$. São precisamente as características tão peculiares desta ferramenta de comunicação que têm atraído os grupos neonazistas. Em um mundo cada vez mais conectado presenciamos o acelerado processo de aprimoramento da Internet que oferece diversos recursos para a construção de páginas virtuais. A chamada web 2.0 não significou apenas um avanço nos sistemas e programas inseridos na estrutura da Internet como também modificou a forma de interatividade estabelecida entre os homens e a rede:

\footnotetext{
${ }^{7}$ Ciberespaço, termo usado pela primeira vez pelo escritor de ficção científica William Gibson, no livro Neuromancer, para referir-se a um lugar onde os cidadãos do futuro estão destinados a habitar (GIBSON, 2002). Posteriormente, o termo foi tomado por Pierre Lévy, que compreende ciberespaço como "um meio, espaço no qual surge às interconexões entre os computadores, sendo este espaço responsável por abrigar não apenas a estrutura material da comunicação digital, como também, o universo oceânico de informações que ele abriga e os seres humanos que navegam e alimentam esse universo". Cf.: LÉVY, Pierre. Cibercultura. Trad. Carlos Irineu da Costa. São Paulo: Ed. 34, 1999: 17.
} 
A diferencia de los primeiros sitios en donde los ciber navegantes sólo eran espectadores pasivos, en la web 2.0 los usuarios agregan o deciden el contenido. En la mayoría de los casos, quienes crean el sitio establecen las normas sobre qué cuestiones pueden ser publicadas (BRAYLAN , 2010: 80).

A partir dessa interatividade, além de permitir que os internautas naveguem nas ondas ópticas da rede e acessem suas páginas digitais, também possibilita a criação do próprio espaço virtual sendo possível a construção de um mundo particular, mesmo que seja em dimensões virtuais. É com base nesta perspectiva que grupos neonazistas têm agido, principalmente, no desenvolvimento de seus sítios.

Por meio dos infinitos caminhos abertos no meio digital o processo de divulgação desses materiais ganhou dois importantes aliados, a rapidez e o alcance quase ilimitado fornecido pela web. Nestes ambientes, eles conseguem montar salas de bate-papo, chats, fóruns de debates, compartilhar diversos materiais e trabalhar com diferentes formas de imagens, distribuindo-as rapidamente através de downloads. Entre esses grupos chamamos a atenção para as atividades desenvolvidas através do website brasileiro Valhalla88.

\section{Valhalla88.com e o revisionismo online}

Criado em 1997, com eletrônico (http://www.libreopinion.com/members/sul88/index.html), o site brasileiro nazista Sul88/Valhalla88, ${ }^{8}$ esteve até o ano de 2005 como membro do portal argentino Ciudad Libertad/Libre Opinión (www.libreopinion.com) $)^{9}$ e filiado à organização $N S D A P / A O^{10}$ (http://www.nazi-lauck-nsdapao.com/) dos Estados Unidos. A partir de 2006, o sítio teve seu endereço eletrônico modificado para (www.valhalla88.com/) em decorrência das alterações

\footnotetext{
${ }^{8} \mathrm{O}$ número 88 faz referência à oitava letra do alfabeto "h". Deste modo, temos "HH", uma alusão à saudação nazista "Heil Hitler".

${ }^{9}$ O Ciudad Libre Opinión é um portal argentino criado por Alejandro Carlos Biondini, em 1999. O portal é oriundo da antiga revista Alerta Nacional, de 1983 e tem como uma de suas principais características ser um servidor host, ou seja, atua como um hospedeiro de outros sítios eletrônicos, oferecendo condições para aqueles que se afiliem a ele possam divulgar seus materiais na Internet. O Libre Opinión continua em atividade.

${ }^{10}$ O NSDAP é uma organização criada por Gerhard Rex Lauck, na década de 1970. De acordo com a própria organização, seu objetivo é dedicar-se a sobrevivência da raça branca. "A atividade e militância do NSDAP/AO são internacionais. Camaradas Nacional Socialistas de todo o mundo são abastecidos de literatura Nacional Socialista publicada em diversas línguas, incluindo Inglês, Alemão, Dinamarquês, Sueco, Húngaro, Holandês, Francês, Espanhol, Português e Italiano." Link disponível em: http://web.archive.org/web/20050311215510/http://www.nazi-lauck-nsd acesso em 26 de junho de 2012.
} 
que sofreu após ter sido retirado do servidor argentino ${ }^{11}$ e passou a ser conhecido apenas por Valhalla88. ${ }^{12}$

O revisionismo histórico e o ativismo político marcaram, de maneira significativa, as páginas virtuais do Valhalla. Este grupo intencionava formar um movimento de ativistas, fazendo uso das ideias difundidas por autores revisionistas para, segundo eles, "educar" seus militantes. A negação do holocausto foi um dos principais temas encontrados ao longo das páginas virtuais do sítio. A intensa propaganda antissemita encontrada neste website incluía textos (geralmente artigos em $p d f$ ) e imagens (em formatos variados, gif, jpeg, png).

O grupo unia elementos textuais e visuais com o objetivo de desumanizar a figura do judeu. A utilização de textos produzidos por diversos autores revisionistas ${ }^{13}$, juntamente com a publicação de imagens diversas (charges, caricaturas, cartoons, HQs), constituíam um conjunto fértil de materiais que nutriam o imaginário dos neonazistas brasileiros.

A atuação dentro do ciberespaço proporcionou aos criadores e mantenedores do Valhalla alguns privilégios decorrentes das especificidades do próprio meio virtual. Livre de fronteiras, versátil, flexível, de fácil manipulação e baixo custo, esse ambiente interferiu diretamente na reconstituição das abordagens realizadas pelos neonazistas. Os textos e as imagens apresentados pelo site seguem um padrão específico.

No caso dos textos, estavam alocados no espaço destinado a Artigos e dispostos em links, sendo necessário apenas um click para que o internauta pudesse fazer a leitura ou o download. Dessa maneira, o arquivo não comprometia a estrutura do site, sendo possível a inclusão de diversos arquivos em uma mesma página virtual. Outra característica comum aos materiais disponibilizados na internet é a existência de palavras hiperlincadas. Isso significa que em um texto é possível ter acesso a outras páginas relacionadas à temática discutida. Com

\footnotetext{
${ }^{11}$ No final de 2004, por meio de uma ação conjunta entre o Ministério Público Federal e o Ministério Público do Rio Grande do Sul, contando com a ajuda da Interpol, o sítio brasileiro foi removido do domínio digital do Ciudad Libre Opinión. Em meados de 2005, o Valhalla88 conseguiu se hospedar em um servidor (host) norteamericano não identificado. Em 2007 o site foi definitivamente retirado do ciberespaço e parte de seu material arquivado no sítio espanhol NuevOrden (www.nuevorden.net).

12 O nome Valhalla (Valhall ou ainda Válala), segundo a mitologia germânica, é o "paraíso dos heróis."A morada dos falecidos e a terra dos vivos se parecem, uma refletindo a outra como um jogo de espelhos que só reproduziriam cenas de alegres violências. A diferença é que uma é visível e a outra invisível. A Valquíria passa de uma para à outra conduzindo o herói morto da luta ao Paraíso de seu sonho. O Válala é imaginado segundo o modelo dos locais de combate, em que se afirma um extravasamento de energia em virtudes guerreiras amorosas. Sonho de combate: batalhas repetidas, das quais os mortos se levantaram para participar de festins. Símbolo dessa energia idêntica a si mesma, que passa de um mundo ao outro; símbolo de um paraíso no outro mundo idêntico à vida com a qual o guerreiro sonha neste mundo (CHEVALIER, 2003).

${ }^{13}$ Entre eles podemos citar Paul Rassinier; Robert Faurisson; Reverendo I. B. Pranaitis; Richard Harwood; Alfred Rosenberg. Cf.: VALHALLA88. Página principal, 2007. Disponível em: http://web.archive.org/web/20070528050846/http://www.valhalla88.com acesso em 26 de junho de 2012.
} 
essa estratégia o compartilhamento de material se tornava mais rápido e eficiente, uma vez que o máximo de informação sobre o assunto era disposto num mesmo texto.

Geralmente esses hiperlinks apareciam no site brasileiro através do banner de algum grupo neonazista que compartilhava das mesmas ideias revisionistas, a exemplo do portal argentino Ciudad Libre Opinión e do sítio neonazista espanhol, NuevOrden ${ }^{14}$. Nesse caso, eram publicados textos ou comunicados fazendo referência ao revisionismo, no qual esses websites eram citados e, ao invés de uma citação convencional contendo nota explicativa, o nome do sítio ou seu banner era transformado em link que permitia ao internauta sair do texto direto para a página virtual desses grupos, com apenas um click. Essa pode ser considerada outra estratégia de difusão do revisionismo, visto que ao disponibilizarem nesses textos e/ou comunicados páginas de outros websites contendo mais material revisionista, além de contribuírem para a propagação dessas ideias, servia de ensejo para a articulação entre esses sites.

As imagens, especificamente os cartoons que serão objetos de nossas análises, reforçavam as ideias expostas nos artigos. Neles, como veremos mais adiante, podíamos perceber que o texto e o traço do desenho eram unificados, resultando na caracterização e construção do inimigo a ser combatido. Assim, o judeu tinha sua imagem comumente associada à estrela de Davi e ao Kipá, além disso, eram acrescentados outros elementos (dinheiro, animais, monstros) no intuito de identificá-los à figura do mal. Desse modo, o cartoon não se configurava como mero desenho exposto em uma página digital. Ao fazer o donwload o neonazista poderia utilizá-lo, como geralmente o fazia, como instrumento de propaganda. A panfletagem, atividade comum aos membros do Valhalla88, era realizada através de pequenos textos nos quais as imagens exerciam papel importante na transmissão da ideia central do movimento, a luta contra o sionismo.

A partir desse momento realizaremos uma análise de alguns artigos encontrados no sítio brasileiro durante o período de 2003 a 2007. Em seguida, utilizaremos os elementos textuais associados aos visuais (cartoons) para demonstrar como os neonazistas brasileiros construíam a imagem do inimigo, o judeu.

\section{$O$ antissemitismo através de textos}

\footnotetext{
14 NuevOrden é um sítio espanhol, criado em 1997. Possuindo uma versão em português, esse website armazenou material do Valhalla88 após este ter sido retirado do ciberespaço pelas autoridades brasileiras em cooperação com a Interpol, em 2007.
} 
No website brasileiro era difundida a clássica ideia revisionista a respeito do Holocausto que consistia em sustentar que "toda a História sobre os fatos ocorridos durante a Segunda Guerra foi propagada pelos vencedores. [...] A dita História foi escrita com base em propaganda de ódio e mentiras e não em fatos" (VALHALLA88, 2007). Ainda segundo os idealizadores do sítio:

A intenção dos revisionistas do Holocausto não é justificar ou fazer debates políticos e filosóficos sobre o que foi o Nacional-Socialismo, mas uma análise histórica imparcial e correta sobre o que realmente ocorreu e o que não ocorreu no período da Segunda Guerra Mundial. Graças a história do suposto Holocausto, foi tomado para os Judeus um pedaço de terra no Oriente Médio chamado Palestina, e que agora chama-se Israel. O Estado de Israel até hoje recebe bilhões de dólares de indenização da Alemanha pelos supostos crimes para se armar contra o Estado palestino. Os Judeus se tornaram um povo incriticável, pois quem os denuncia logo é taxado de "fascista" ou "nazista". E TUDO isso depende do mito da vitimização judia do Holocausto. Os defensores da história oficial nunca realizam um debate justo com os revisionistas, mas os proíbem e os encarceram porque tem medo de que a verdade seja revelada (VALHALLA88, 2007).

A suposta "vitimização judia do Holocausto" estava entre algumas das principais justificativas para a realização de ataques feitos à comunidade judaica. Para os criadores do Valhalla, através dessa vitimização o complô formado pelo sionismo internacional e a formação do Estado de Israel que, segundo eles, é mantido financeiramente devido ao "mito do holocausto", seriam profundamente fortalecidos. Dessa maneira, a intenção dos revisionistas seria a de realizar uma espécie de desmascaramento sobre o real objetivo dos judeus.

Para os mantenedores do Valhalla, parecem estar bem claros os possíveis objetivos dos judeus ao utilizarem o "mito do holocausto":

A exploração dessa farsa/mentira, por incrível que pareça, rende bilhões de dólares, até hoje, aos criadores/inventores/exploradores do chamado 'holocausto judeu', pagos pela Alemanha - sob ameaças de boicotes comerciais e outras punições por parte dos vencedores - pois nenhum dos 68 países que estiveram em guerra com a mesma assinou qualquer tratado de Paz até agora, fato que a torna totalmente submissa e que nos leva a taxá-la de ser uma Colônia Sionista. A Alemanha, além de pagar tudo o que os "vivos" exigem, por um nefasto Tratado de São Francisco, de 28.06.1945, feito sob os auspícios da O.N.U., ainda deve zelar e impedir que possa surgir um Partido Nacionalista forte, motivo pelo qual os governantes alemães 
tanto perseguem esses tipos de movimentos, logo apelidados de nazistas ou neonazistas pela imprensa, que os acusa injustamente por qualquer arruaça ou crime que acontece no país (VALHALLA88, 2005).

Desta maneira, segundo difundido no website, o Holocausto se transformou em uma história valiosa utilizada pelos judeus para torná-los um grupo incriticável. "Com um tipo de religião secular, ela dá uma junção emocional entre os judeus e seus líderes. É uma poderosa ferramenta nas campanhas para conseguir fundos judaicos, e é usado para justificar a 'ajuda' norte-americana a Israel" (VALHALLA88, 2003).

A publicação de textos informativos relacionados ao que eles definiam de a "indústria do holocausto" era exaustivamente apresentada nas páginas do website. Em um desses trabalhos, produzidos por um autor anônimo, intitulado "Os mentirosos números sobre Auschwitz", encontrado no Valhalla em 2005, era divulgado listas sobre os supostos números de mortos anunciados pela imprensa mundial e por diferentes instituições após o fim da Segunda Guerra Mundial. A seguir, destacamos alguns dados informados nessas listas:

\begin{tabular}{|c|c|c|}
\hline Data & Fonte de informação & $\mathrm{N}^{\circ}$ de mortos \\
\hline 31.12 .1945 & Painel francês de investigação de crimes nazistas & 8.000 .000 \\
\hline 19.08 .1998 & Chefe do Rabinato da Polônia (Süddeutsche Zeitung) & 6.000 .000 \\
\hline 20.04 .1978 & Le monde (Diário francês) & 5.000 .000 \\
\hline 23.01 .1995 & Die Welt (Dirário alemão) & 5.000 .000 \\
\hline 20.04 .1989 & Eugen Kogon (Livro “Der SS Staat”, pg. 176) & 4.500 .000 \\
\hline 31.12 .1952 & Der Neue Herder (Encyclopidia, Germany) $7^{\mathrm{a}}$ ed., p. 214 & 4.500 .000 \\
\hline 01.10 .1946 & IMT-Doc.008-Urss (Tribunal Militar de Nuremberg) & 4.000 .000 \\
\hline 02.05 .1997 & USA-Today (Diário norte-americano) & 4.000 .000 \\
\hline 26.07 .1990 & Allgem.Jüdische Wo.Zeit (Semº judaico Bonn) & 4.000 .000 \\
\hline 08.10 .1993 & ZDF - Nachrichten (TV alemã) & 4.000 .000 \\
\hline 01.10 .1946 & IMT-Doc.3868-OS (Tribunal de Nuremberg) & 3.000 .000 \\
\hline 01.01 .1995 & Damals (Revista mensal alemã, oficial, de Bonn) & 3.000 .000 \\
\hline 18.07 .1990 & The Peninsula Times (Diário de São Fracisco, USA) & 2.000 .000 \\
\hline 11.06 .1992 & Allgem.Jüdische Wo.Zeitung (Semanário judaico) & 1.500 .000 \\
\hline 08.10 .1993 & ZDF (TV alemã) & 1.500 .000 \\
\hline 23.01 .1995 & Die Welt (Diário alemão) & 1.500 .000 \\
\hline 01.09 .1989 & Le monde (Diário francês) & 1.433 .000 \\
\hline 27.01 .1995 & Die Welt (diário alemão) & 1.100 .000 \\
\hline 27.01 .1995 & Inst $^{\circ}$ de Hist. Contemporânea de Munich & 1.000 .000 \\
\hline
\end{tabular}

\section{Hilstortorias}




\begin{tabular}{|c|c|c|}
\hline 31.12 .1989 & Pressac, Auschwitz, da Fundação Beate Klarsfeld & 928.000 \\
\hline 27.09 .1993 & Die Welt (Diário alemão) & 800.000 \\
\hline 22.01 .1995 & Welt am Sonntag (Ed. Dominical) & 750.000 \\
\hline 01.05 .1994 & Focus (Semanário alemão-revista) & 700.000 \\
\hline 31.12 .1994 & Pressac, Cremat’o Fund.Beate Klarsfeld & 470.000 \\
\hline 31.05 .1994 & Livro Stalins Vernichtigungskrieg, p.302, de Hoffmann & 74.000 \\
\hline 17.08 .1994 & Cruz Vermelha Internac., de Arolsen (ref.abr.:10428) & 66.206 \\
\hline
\end{tabular}

Tabela 1: Informações obtidas para a confecção da tabela acima mencionada foram retiradas do texto "Os mentirosos números sobre Auschwitz". Esse texto está disponível através do link: http://web.archive.org/web/20050516002940/http://www.valhalla88.com acesso em 26 de junho de 2012. A tabela não está em sua forma original, foram selecionados alguns dados para demonstrar as estratégias utilizadas pelo grupo do Valhalla88 na construção de suas ideias sobre os campos de concentração nazistas.

Ao apresentar as informações dessa tabela, os criadores do site objetivavam demonstrar uma possível divergência na contabilidade dos números de mortos encontrados em Auschwitz-Birkenau. Esta divergência acabava confirmando, de certa maneira, uma inexatidão nos cálculos e, consequentemente, contribuía para dar credibilidade às teorias revisionistas.

Na tabela acima, há informações numéricas que supostamente foram divulgadas logo após a abertura dos campos e que ao longo do século XX foram novamente recalculadas, chegando ao número de 66.206 mortos. Estes dados foram fornecidos, segundo o texto publicado no sítio, pela Cruz Vermelha Internacional.

A suposta divergência existente em relação ao número de mortos nos campos de concentração por muito tempo alimentou as teorias revisionistas, concedendo legitimidade as suas pesquisas sobre o holocausto. Ao final do século XX e início do XXI, movimentos extremistas ainda se debruçam sobre estes números, na tentativa de revalidar suas ideias políticos na contemporaneidade.

Um dos principais pontos de discussão levantados no sítio está associado à negação de Auschwitz como um campo de extermínio. Segundo eles, esse campo "era um centro de internamento e parte de um complexo manufatureiro de grande escala. Combustível sintético foi produzido lá, e seus prisioneiros foram utilizados como força de trabalho" (VALHALLA88, 2003). Para reforçar essa ideia, nada mais adequado do que utilização de trabalhos revisionistas produzidos por personalidades reconhecidas no meio acadêmico, a exemplo de Robert Faurisson. 
O artigo intitulado "A piscina de Auschwitz", escrito por esse autor e divulgado no site em 2003, foi um dos muitos trabalhos de Faurisson utilizados no Valhalla88. Nesse texto, eram apresentados relatos de testemunhas que supostamente estiveram em Auschwitz e afirmavam que ele não era como descrito pelos vencedores da Segunda Guerra. O autor trazia o relato de Marc Klein, professor de medicina da Faculdade de Strasburgo de origem judaica que foi prisioneiro nesse campo de concentração durante a guerra. Nas palavras de Klein:

As horas de trabalho eram diferentes aos domingos e feriados, quando a maioria dos comandos estavam em descanso. Chamadas eram feitas por volta do meio dia, e as tardinhas dedicadas ao descanso ou escolhia-se entre atividades culturais ou esportivas. Futebol, basquete e partidas de póloaquático (em uma piscina a céu aberto construída para os detentos por dentro do perímetro) atraía multidões de observadores (Klein, apud FAURISSON, 2003: 1).

Nesse relato percebemos a idealização de um ambiente completamente destituído de qualquer elemento que o vincule a violência. Ao contrário, a imagem criada é a de um espaço harmonioso, saudável, no qual após cumprir seu trabalho, o indivíduo era incentivado a praticar os mais variados tipos de atividades desportivas e, ao mesmo tempo, estimulando o desenvolvimento cultural. Numa perfeita alusão ao Arbeit Macht Frei (o trabalho liberta), frase escrita na maioria dos portões dos campos de concentração nazistas.

Distante dessa imagem, Auschwitz foi e deve continuar sendo visto como um dos maiores exemplos de desumanização e burocratização da morte humana. Nesse ambiente, vidas foram ceifadas em nome de uma insana busca pela perfeição racial. E, a partir do momento em que tiveram seus caracteres físicos desfigurados, seus corpos tatuados e seus nomes substituídos pelas matrículas numéricas, (RAMOS, 2006: 35), delas foi retirado o direito a individualidade, o que as tornavam únicas como seres humanos, consolidando a ideia de "transcendência do estranhamento" (SILVA, 2005: 142). Assim, o fascismo negava a existência do outro, através da criação de um poderoso código de ação e, armado com um sistema ideológico e mental adequado, que identificava em si mesmo valores absolutos transformando qualquer diferença em objeto de eliminação violenta (SILVA, 2005: 149).

Em outro texto bastante citado e divulgado no Valhalla a partir de 2003, intitulado "Olá, sou judeu," nos deparamos com o que seria uma espécie de depoimento feito por um hipotético judeu, no qual ele próprio expõe algumas características do seu povo. Estas características, geralmente, estão relacionadas a elementos negativos. 
O intuito do artigo, segundo seu autor, J. R. Colson, era alertar a sociedade sobre o perigo representado pelos judeus que, de acordo com o texto, estão espalhados por todos os lugares e ocupam diversos cargos importantes em instituições públicas e privadas, incluindo os meios de comunicação. Assim, nas palavras do suposto judeu era admitido que eles haviam se tornado especialistas em prevenir o antissemitismo na denominada cultura dominante devido ao engajamento em "certas atividades muito especificas, em áreas que nos davam um controle melhor sobre a cultura hospedeira" (COLSON, 2003: 1-4).

Se o texto anterior centrava-se na reconstrução da imagem de Auschwitz, no artigo de Colson o alvo era a caracterização do judeu. No primeiro, é o espaço/campo que se transforma em um ambiente destituído de qualquer elemento de violência, no segundo, é o indivíduo que se constitui como dotado de todo mal. A ideia de carrasco e vítima é invertida, consequentemente a culpa passa a ser do outro, nesse caso o judeu.

Ao longo do artigo, Colson fazia referência à coesão da comunidade judaica sugerindo uma espécie de constituição de um complô que serviu para ajudá-los a sobreviver e, ao mesmo tempo, os fortaleceu diante dos demais povos, favorecendo uma possível tomada de poder. Segundo escrito no artigo, "curiosamente, de uma maneira bem darwinista, a opressão interminável na verdade acabou por nos ajudar. Ela nos forçou a nos tornar mais coesos, muito mais planejadores a longo prazo, e muito mais espertos do que os não-judeus [...]" (COLSON, 2003: 1). Nesse fragmento, Colson insinuava que os judeus, sendo um povo diferente de qualquer outro, tinham como objetivo proteger e beneficiar somente a sua comunidade, em nome de um propósito maior, a total dominação política, cultural e financeira sobre os "não-judeus".

Seguindo nesse texto, chamamos a atenção para o trecho:

Nós também tínhamos que aprender a como mentir na ponta da língua, sobre qualquer coisa que pudesse ser perguntada à nós, de forma a prevenir mais opressão, e esses século de mentira, automaticamente acabaram na verdade se tornando integrados à nós, geneticamente" (COLSON, 2003: 1).

Nele o autor afirma que o ato de mentir está imerso no povo judaico de forma tão intensa que se tornou parte de sua genética, inerente a seu caráter, está em seu DNA. Esta afirmação converge com as palavras de Adolf Hitler escritas no Mein Kampf (Minha Luta), que se referia ao judeu como sendo "o maior mestre da mentira e a mentira e a fraude são as únicas armas da sua luta” (HITLER, 1925: 220-331). 
Simplistas e disformes essas justificativas nutriam o imaginário dos membros do Valhalla88. Um exemplo disso é a postagem feita na Voz de $\operatorname{Odin}^{15}$, em 2005, o autor da publicação não teve seu nome revelado. Em suas palavras não é difícil perceber como as ideias difundidas por meio dos artigos divulgados no website foram tomadas pelos seus membros:

O que Hitler queria criar era uma raça nobre, pura, com o que tivesse de mais nobre e mais belo, o que poderíamos ver de errado nisso? Muitos dos que acreditam no Holoconto argumentariam que os judeus foram perseguidos, ou que não haveria espaço outros num sistema como esse (como se o atual sistema não fosse também excludente). A questão dos judeus, independente do que se pode interpretar era localizada, pois eles estavam decididos a destruir a Alemanha. O mérito de se construir uma grande raça de super-homens até transcenderia essa questão. Mas, independente de ter havido alguma divergência ou conflito entre o sionismo e o nacional-socialismo, os judeus sempre atacariam qualquer um que se opusesse a sua dominação, ou qualquer um que quisesse ser mais do que massa, populacho, esse mesmo populacho que existe, por exemplo, nos EUA, a nação mais zog do mundo. Os judeus não tem nada de valor que possa ser atribuído a eles mesmos, e no entanto, invejam e odeiam tudo aquilo que demonstre ser superior, ter qualidades e virtudes solares, divinas, de poder, virtudes imperiais. Eles só valem pelo "TER" e não pelo "SER". [...] É por isso, que eles mexem, sempre que podem, nas estruturas econômicas dos países, para criar recessões e misérias. Por isso que tomam conta da mídia, para pregar novos valores de consumir, ao invês (sic) de ser (VOZ DE ODIN, 2005, grifo nosso).

Aqui vemos como os principais elementos vinculados aos ideais revisionistas foram apropriados. Como mencionado anteriormente, eximir Adolf Hitler de todo e qualquer envolvimento sobre holocausto ou o extermínio de judeus é o primeiro objetivo dos neonazistas; o segundo é desvincular a imagem dos campos de concentração à de campos de extermínio e, por fim, o terceiro objetivo é a transmutação da vítima em carrasco.

Como bem nos lembra Theodor W. Adorno, as explicações sobre Auschwitz, assim como os outros campos de concentração nazistas têm de ser procuradas nos perseguidores e não nas vítimas. "Não são os assassinados os culpados, nem sequer no sentido sofístico e caricato que alguns ainda gostariam de construir. Culpados são somente aqueles que, fora de

\footnotetext{
${ }^{15}$ Voz de Odin (vozdeodin@ bigfoot.com) era o espaço disponibilizado pelo Valhalla88 para contato com seus leitores. Neste ambiente também eram compartilhados materiais, cartazes e textos, por exemplo, entre os membros e simpatizantes do sítio brasileiro. O nome Odin faz referência ao Deus Vótan (ou Odin), Deus insaciável que sempre quer mais combates, mais força, mais prazeres, mais mulheres; quer impor a todos e a tudo a lei de sua vontade; à procura do poder absoluto; o arquétipo de um Fausto. É também o deus dos mortos, que percorre os campos de batalha para oferecer as vítimas às Valquírias. Símbolo da violência cega: viaja nas dobras de um manto azul da noite, com um grande chapéu escondendo seu rosto; só tem um olho e aparece inesperadamente (CHEVALIER, 2003).
} 
si, deram neles vazão ao seu ódio e à sua fúria agressiva” (ADORNO, 1974: 3). Devemos sempre nos lembrar de que "ao invés de congregar, significado do termo humanidade, a mensagem dos campos de concentração era a não-aceitação do outro (étnica, religiosa, política, econômica, sexual e socialmente)" (RAMOS, 2006: 1).

\section{Cartoons, a configuração dos inimigos}

Através dos cartoons, as descrições produzidas por meio dos artigos ganharam formas e exerceram um importante papel na consolidação da ideia que se queria construir sobre esse personagem (judeu). Se nos artigos havia uma clara referência à idoneidade do caráter judaico, nos cartoons os caracteres físicos atribuídos a eles reforçavam a construção de uma figura nociva.

A combinação entre as informações textuais e visuais resultou na criação de seres carregados de elementos estigmatizantes. Uma estigmatização que pode ser traduzida como exclusão simbólica e que coloca em jogo um certo número de estereótipos negativos, transformando os estereotipados em supostos manchados ou que ameaçam marchar-se. Tendo como principal efeito a máxima polarização entre o par - Nós versus Eles - (os nossos versus o inimigo) (TAGUIEFF, 1997: 79).

A seguir, apresentamos alguns exemplos de imagens utilizadas no Valhalla88.
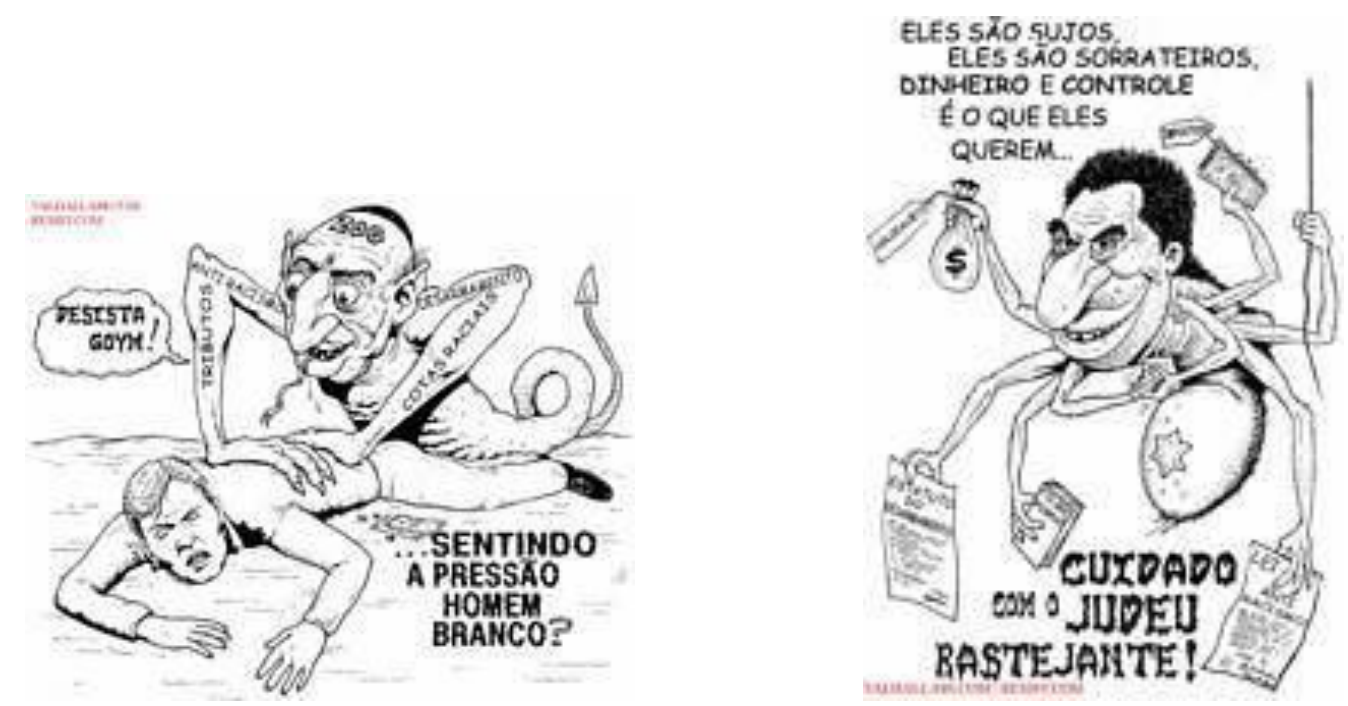

Figuras 1, 2: Imagens disponibilizadas no site Valhalla88, de 2005, através da seção cartoons. Disponível em: http://web.archive.org/web/20050317190418/http://www.valhalla88.com acesso em 26 de junho de 2012. 

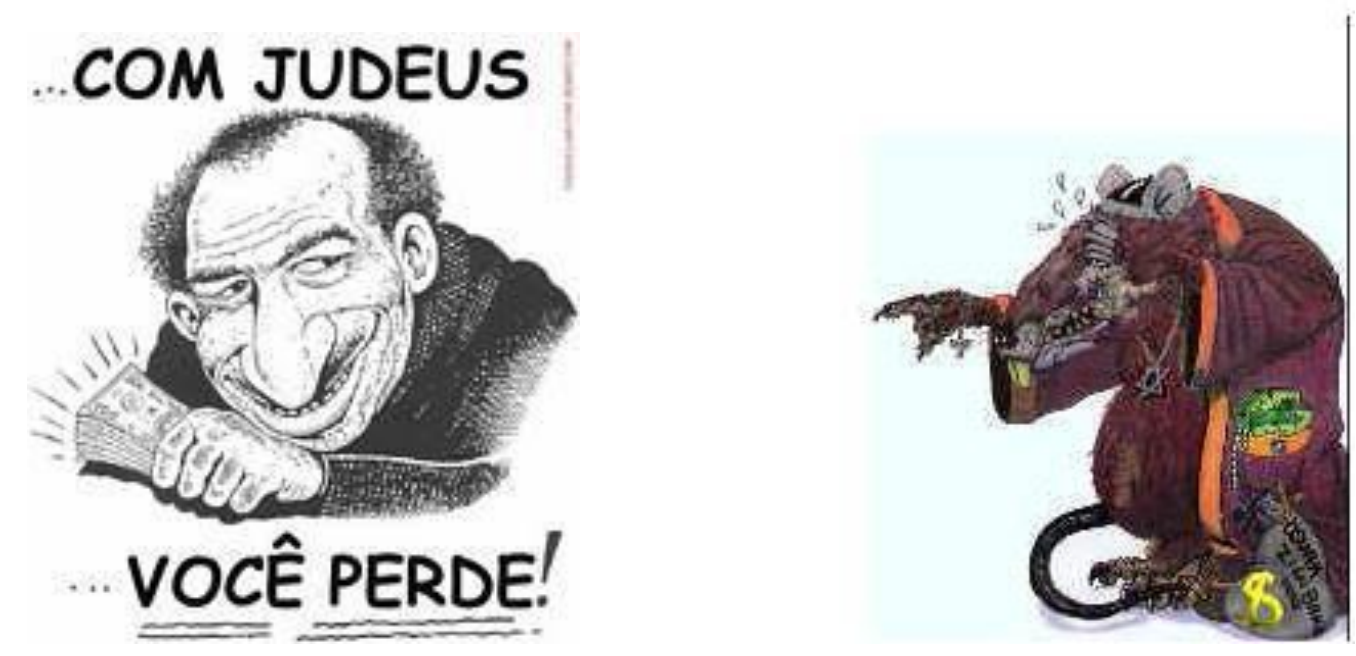

Figuras 3, 4: Imagens disponibilizadas no site Valhalla88 através da seção cartoons e do texto intitulado "Olá, sou judeu" encontrado através do link artigos. Disponíveis, respectivamente em: http://web.archive.org/web/20050317190418/http://www.valhalla88.com acesso em 26 de junho de 2012 e http://web.archive.org/web/20030827220108/http://libreopinion.com/members/sul88/valhalla88.html acesso em 06 de setembro de 2012.

Os judeus apareciam em figuras de maneira deformada, com partes do corpo desproporcional - nariz grande, lábios exageradamente grossos -, ou eram representados em formas de animais - aranhas e ratos. Além disso, também apareciam como monstros, em uma espécie de alusão a figura do mal. Possuíam um olhar malicioso e traziam consigo seus principais símbolos religiosos, o kipá e a estrela de Davi. Geralmente sua imagem estava relacionada ao dinheiro, ao lucro ou a usura. Responsabilizados pela destruição da solidariedade racial branca, eram definidos como sujos, sorrateiros, rastejantes.

De acordo com Pierre-André Taguieff, "a desumanização do inimigo, demonizado ou animalizado, produz o distanciamento psicológico entre carrasco e vítima, sem a qual o homicídio de massa, mais ou menos banalizado, não pode ter lugar” (1997: 79). A partir dessa perspectiva, é possível construir não apenas os inimigos como também uma série estratégias para destruí-los, sem que isso crie nos carrascos algum tipo de remorso.

O antissemitismo moderno, segundo Wagner Pinheiro Pereira, transformou "os judeus em 'mercadores do mal', em representantes de uma 'raça inferior'" (2012: 407) e a eles atribuiu-se a responsabilidade pela suposta idealização de um plano de dominação política, econômica e cultural (mito da conspiração judaica). É importante lembrar, como bem disse 
Paul Hockenos, que "embora a essência do novo antissemitismo tenha muito em comum com o anterior, invoca o mal do judaísmo sob novas condições históricas [...]. O antissemita contemporâneo é também o racista, o homofóbico, o católico conservador e o nacionalista provinciano." (1995: 315-316). Ou seja, é uma confusa combinação de apelo nostálgico a um tempo jamais vivido, mas sempre idealizado, com um elogio à tecnologia na busca por conquistas futuras.

Como foi possível perceber através das páginas virtuais do Valhalla88, a disseminação do ódio a este personagem (judeu) continua sendo um dos principais objetivos de grupos neonazistas no século XXI. Para tanto, eles tem constantemente acionado à liberdade de expressão.

A palavra liberdade assumiu um papel fundamental nas sociedades, principalmente a partir do fim da Segunda Guerra Mundial. Este termo se configura como o principal elemento de qualquer sociedade que tenha por objetivo adquirir o status de democrática.

Para além dessa função, o termo liberdade também tem sido apropriado por diversos grupos e movimentos políticos para legitimarem suas ações e propostas. Este termo passou a ser utilizado como uma espécie de marca para partidos políticos de extrema-direita, nacionalistas, xenofóbicos e/ou antissemitas. Entre esses partidos destacamos o Partido da Liberdade, na Holanda, dirigido por Geert Wilders; o Partido Austríaco da Liberdade que Jörg Haider dirigiu até sua morte, na Áustria; a Liga do Povo da Liberdade, conduzido por Umberto Bossi e o Povo da Liberdade de Sílvio Berlusconi, ambos da Itália (TODOROV, 2012: 11).

Segundo Tzvetan Todorov, "o principal acontecimento político do século XX foi o choque entre o espírito democrático e o espírito totalitário, apresentando-se o segundo como um corretivo dos defeitos do primeiro" (TODOROV, 2012: 12). Ao fim da Segunda Guerra, contabilizado o número de mortos e a intensidade de sofrimentos ocorridos neste período, a sociedade do século XX deu-se conta de que o espírito totalitário continha em sua origem o gene da destruição e que a sua derrocada significava a vitória da democracia. Dessa maneira, a democracia se transformou no oposto imediato de tudo que os regimes totalitários representavam e, ao adquirir esta característica, ela passou a servir como álibe para movimentos políticos com diversas finalidades.

No século XXI, temos presenciado uma onda de movimentos políticos que, utilizando termos como liberdade e exaltando a defesa da democracia, tem buscado legitimar-se no âmbito político e social. No entanto, o uso desses termos, especialmente da liberdade, em 
alguns casos, tem servido para legitimar comportamentos preconceituosos diversos. Diante das abordagens empregadas por grupos neonazistas nesse século, percebemos que:

[...] a democracia produz, nela mesma, forças que a ameaçam, e a novidade de nossos tempos é que essas forças são superiores àquelas que a atacam de fora. Combatê-las e neutralizá-las é tanto mais difícil quanto mais elas invocam o espírito democrático e possuem, assim, as aparências da legitimidade (TODOROV, 2012: 14).

A utilização dos princípios democráticos por esses grupos tem servido para denotar uma aparente busca pela dignidade humana. No entanto, esta estratégia tem mascarado o caráter violento e intolerante desses movimentos. O que temos visto são grupos de jovens agindo de forma violenta contra pessoas que eles consideram diferentes e, dessa maneira, inadequadas para viverem no mundo que pretendem construir.

No universo virtual, um território sem donos e sem fronteiras, no qual as informações e as pessoas que navegam neste espaço se tornam uma só coisa, a liberdade de expressão/pensamento atinge seu ponto máximo. É nesse lugar sem caminhos fixos que "os transgressores não deixam pegadas [...] e, cada um é uma realidade tão verdadeira como as sombras da caverna de Platão” (ALEXANDER apud GIBSON, 2002: 259).

\section{Considerações finais}

O desenvolvimento e a popularização dos meios de comunicação, principalmente da Internet, no final da década de 1990, abriu um novo espaço que tem permitido aos homens estabeleceram novas formas de relacionamentos - políticos, sociais, culturais e econômicos. Amparados por todo um conjunto de recursos tecnológicos, a atuação humana dentro desse ambiente foi potencializada tanto em sua dimensão quanto em seu alcance.

Paralelo a essa popularização, movimentos de extrema-direita identificados com o nazismo eclodiram em diversas partes do mundo e encontraram no ciberespaço uma alternativa para organizarem seus movimentos políticos. Não há como negar que a web contribui para o aprimoramento das propagandas desses movimentos, diversificando suas formas de abordagens e ampliando a capacidade de divulgação de suas ideias.

Ao observarmos a organização do Valhalla88 dentro da rede percebemos que esse grupo possuía um articulado projeto de ativismo antissemita lançado e reforçado através dos recursos obtidos através do meio digital. Nas mais de 700 páginas virtuais desse sítio, havia 
sido construído um ambiente que oferecia inúmeras opções para que qualquer pessoa com interesse no tema pudesse acessá-las sem maiores dificuldades. Não há dúvidas que o Valhalla foi um dos grupos neonazistas mais ativos no Brasil dentro do ciberespaço.

Ainda que o antissemitismo não tenha florescido no Brasil da mesma forma que na Alemanha da primeira metade do século XX, o recado que esse grupo nos deixa também requer atenção e cuidados. O perigo eminente que grupos neonazistas exercem sobre a sociedade não se refere a uma possível tomada de poder a partir da mobilização das massas. Mas, está relacionada efetivamente a violência que eles praticam nas ruas contra homossexuais, negros, imigrantes, judeus, punks. Eles evidenciam em nossa sociedade a persistência de problemas antigos ligados à intolerância étnica, racial, sexual, regional e estética.

\section{Referências Bibliográficas}

ADORNO, Theodor, W. Erziehung nach Auschwitz, In: Stichworte: kritische Modelle 2. Trad. por Aldo Onesti. Frankfurt-Suhrkamp, 1974.

ARÓSTEGUI, Julio. "A crise da historiografia e as perspectivas na virada do século". In: Idem. A pesquisa histórica. Teoria e método. Trad. Andréa Dore. Bauru, SP: EDUSC, 2006.

CHEVALIER, Jean et al. Dicionários de Símbolos: mitos, sonhos, costumes, gestos, formas, figuras, cores, números. 18 ed. Trad. Vera da Costa e Silva. Rio de Janeiro: José Olympio, 2003.

COLSON, J. R. "Olá, sou judeu". Valhalla88, 2003. Texto disponível em: http://web.archive.org/web/20030827220108/http://libreopinion.com/members/sul88/valhalla88.html acesso em 06 de setembro de 2012.

BRAYLAN, Marisa (Comp.). Informe sobre antissemitismo en la Argentina 2009. Delegación de Asociaciones Israelitas Argentinas (DAIA)/Centro de Estúdios Sociales. Buenos Aires, 2010.

FAURISSON, Robert. "A piscina de Auschwitz". Valhalla88, 2003. Disponível em: http://web.archive.org/web/20030827210257/http://libreopinion.com/members/sul88/valhalla88.html acesso em 06 de setembro de 2012.

FERNANDEZ-ARMESTO, Felipe. Verdade: uma história. Trad. Beatriz Vieira. Rio de Janeiro: Record, 2000.

GIBSON, William. Neuromancer. Trad. Abdoulie Sam Boyd e Lumir Nahodil. S/L, [data original da publicação 1984]. [versão digital - ano 2002]. Disponível em: https://www.sabotagem.revolt.org.

HITLER, Adolf. Minha Luta. (Versão digital), 1925. Disponível em: www.InLivros.net acesso em 15 de dezembro de 2013.

HOBSBAWM, Eric. "Dentro e fora da história”. In: Idem. Sobre História. Trad. Cid Knipel Moreira. São Paulo: Companhia das Letras, 1998.

HOCKENOS, Paul. Livres para odiar: Neonazismo - ameaça e poder. Trad. Esther Ann Henningsen. São Paulo: Scrita, 1995.

JESUS, Carlos Gustavo Nóbrega de. Anti-semitismo e nacionalismo, negacionismo e memória: Revisão Editora e as estratégias da intolerância, 1987-2003. São Paulo: editora UNESP, 2006.

KRAUSE-VILMAR, Dietfrid. "A negação dos assassinatos em massa do nacional-socialismo: desafios para a ciência e para a educação política,” pp. 103-120. In: VIZENTINI, Paulo Fagundes; MILMAN, Luis (Orgs). 
Neonazismo, Negacionismo e Extremismo Político. Porto Alegre: Editora da Universidade/UFRG: CORAG, 2000.

LÉVY, Pierre. Cibercultura. Trad. Carlos Irineu da Costa. São Paulo: Ed. 34, 1999.

MALERBA, Jurandir. Ensaios: teoria, história e ciências sociais. Londrina: Eduel, 2011.

MELO, Arthur Fernando Soares Borges de. A chegada do negacionismo no Brasil: A obra Holocausto: Judeu ou Alemão? (1987) de S. E. Castan. 2013, 80p. Monografia (Bacharelado em História). Instituto de Filosofia e Ciências Sociais - IFCS História. Universidade Federal do Rio de Janeiro, Rio de Janeiro, 2013.

MILMAN, Luis. "Negacionismo: Gênese e desenvolvimento do extermínio conceitual”. In: VIZENTINI, Paulo Fagundes; MILMAN, Luis (Orgs). Neonazismo, Negacionismo e Extremismo Político. Porto Alegre: Editora da Universidade/UFRG: CORAG, 2000.

PEREIRA, Wagner Pinheiro. O poder das imagens: cinema e política nos governos de Adolf Hitler e de Franklin D. Roosevelt (1933-1945). São Paulo: Alameda, 2012.

RAMOS, Célia Maria Antonacci. As nazi-tatuagens: inscrições ou injúrias no corpo humano? São Paulo: Perspectiva, 2006.

REIS, José Carlos. As iidentidades do Brasil: de Varnhagen a FHC. 4ª ed. Rio de janeiro: Editora FGV, 2001.

TAGUIEFF, Pierre-André. O Racismo. Trad. José Luís Godinho. Instituto PIAGET. Lisboa: Flammarion, 1997 - Collection Dominos.

TODOROV, Tzvetan. Os inimigos íntimos da democracia. Trad. Joana Angélica d'Avila Melo. São Paulo: Companhia das Letras, 2012.

VALHALLA88. "Os mentirosos números sobre Auschwitz", 2005. Disponível em: http://web.archive.org/web/20050516002940/http://www.valhalla88.com acesso em 26 de junho de 2012.

VALHALLA88. "66 perguntas e respostas sobre o Holocausto", 2003. Instituto pela Revisão Histórica. Disponível em:

http://web.archive.org/web/20030827210135/http://libreopinion.com/members/sul88/valhalla88.html acesso em 6 de setembro de 2012.

VALHALLA88. "Entendendo o que é o Nacional-Socialismo", 2007. Disponível em: http://web.archive.org/web/20070516100533/http://www.valhalla88.com acesso em 20 de setembro de 2013.

VIDAL-NAQUET, Pierre. O Revisionismo na História: Os assassinos da memória. Trad. Marina Appenzeller. Campinas, SP: Papirus, 1988.

VOZ DE ODIN, 2005. Disponível em:

http://web.archive.org/web/20050410075147/http://www.valhalla88.com/vozdeodin/vozdeodin.html acesso em 26 de junho de 2012.

\section{Sites acessados}

Nazi Lauck NSDAP/AO - http://www.nazi-lauck-nsdapao.com

NuevOrden - www.nuevorden.net

Radioslam - http://www.radioislam.org/index.html

Revisionismo.com. - www.revisionists.com/revisionists/rassinier.html

Valhalla88 - www.valhalla88.com 